Revista de Estudios Histórico-Jurídicos

[Sección Historia del Derecho Hispano-Indiano]

XXXIII (Valparaíso, Chile, 2011)

[pp. 463 - 484]

\title{
“CORTAR" LA SUSTANCIACIÓN DE UNA CAUSA Y REMITIR LA PENA EJEMPLIFICADOS CON DOS CAUSAS CRIMINALES POR ABIGEATO A FINES DEL SIGLO XVIII EN El ReINo DE ChIle
}

['Cutting' the Substantiation of a Trial and Remitting the Penalty Exemplified With Two Criminal Trials for Cattle Theft by the End of the $18^{\text {th }}$ Century in the Kingdom of Chile"]

\author{
Gilberto Harris Bucher* \\ Universidad de Playa Ancha, Valparaíso, Chile
}

\begin{abstract}
RESUMEN
El trabajo aborda la legislación aplicable al delito de abigeato tanto por el derecho Castellano Supletorio como por disposiciones evacuadas en el derecho originario chileno, y enfatiza en la importancia para el Reino de Chile de las actividades conectadas con la ganadería y la utilización de sus sub productos. $Y$ en lo central se aboca a estudiar la sustanciación de dos causas criminales por abigeato en los años 1792 y 1794 , juicios en los que los fiscales demostraron palmariamente las culpabilidades de los acusados, pero que, y esto es clave en el derecho autogenerado en Chile, fueron finalmente puestos en libertad, a pesar de todas las agravantes, para desahogar las cárceles por haber cumplido gran parte de la pena o por indulto real.

Palabras Clave

Abigeato - "Cortar" una causa - Remisión de la pena.
\end{abstract}

\section{Abstract}

The work deals with applicable law to cattle-theft crime both by the Supplementary Castilian law and by provisions of the Chilean primary law, and emphasizes the importance for the Chilean Kingdom of the activities related with livestock breeding and the utilization of its sub-products. The main focus of this work is the study of the trying of two criminal proceedings for cattletheft in 1792 and 1794, trials where public prosecutors clearly showed the guilty of the defendants, but that, and this is of paramount importance in the self-generated law in Chile, they finally were released despite all the aggravating circumstances. The purpose of this was to clear jails based on the fact that offenders had served a significant portion of their jail time, and on royal pardon.

\section{KEYWORDS}

Cattle-theft, cut a case, remit a sentence.

ReCibido el 12 de mayo y ACEPTADO el 28 de julio de 2011

* Profesor titular de Historia de Chile, Nacional, Contemporánea y Neocontemporánea de la Facultad de Humanidades de la Universidad de Playa Ancha. Dirección Postal: Universidad de Playa Ancha, Facultad de Humanidades, Departamento de Historia, Casilla 34-V, Playa Ancha, Valparaíso, Chile. Dirección electrónica: g.harrisbucher@gmail.com 


\section{INTRODUCCIÓN**}

Al Chile de los siglos XVI y XVII, en el que sería difícil no percibir la absorbente temática bélica, sucede una centuria pródiga en auspiciosos reajustes coloniales que consultan el "establecimiento de nuevos organismos, agencias y funcionarios, depuración y racionalización administrativa en el ámbito de la hacienda pública y municipal, proyectos para dar solución a los asuntos indígenas, mejoramiento de las condiciones existentes en las comarcas, reglamentación encaminada a liberalizar el comercio, estrategias defensivas contra las incursiones de potencias extranjeras, ajustes territoriales para uniformar el cuadro administrativo y eclesiástico y su nomenclatura" ${ }^{1}$, previsoras disposiciones impuestas desde la metrópoli, que indudablemente incidirán en el mejoramiento de la situación existencial del Reino, una vez aplicadas por los funcionarios y organismos correspondientes. Sin embargo, junto a estas diversas disposiciones que serán gradualmente implementadas por la acción gubernativa, según fuesen las necesidades e imperativos locales y regionales, desde el advenimiento de la decimoctava centuria, y concretamente remontando su segunda mitad, se hace patente la existencia de un problema que por su gravedad obligará a extremar las acciones de los justicias, como también la adopción de medidas paliativas y represivas por parte de la autoridad política. Nos estamos refiriendo a la proliferación de la delincuencia en despoblado y, concretamente, a la figura delictual más característica de la campiña chilena: el abigeato ${ }^{2}$.

En lo que respecta al delito que nos ocupa, debemos dejar constancia de dos importantes cuestiones. Por una parte la relación existente entre vagabundaje y abigeato. Un excelente estudio sobre este tópico ha llegado a demostrar de manera patente como "el vagabundaje marcha íntimamente relacionado con el

** La introducción, casi sin modificaciones, es la misma incluida en los prolegómenos de nuestro estudio "Humanitarismo Audiencial en una causa criminal por abigeato en el Reino de Chile, 1774” en REHJ., 19 (Valparaíso, 1997), pp. 143-148.

${ }^{1}$ Cobos, María Teresa, La división territorial de Chile y sus modificaciones. 1700-1818, en Coloquios de los profesores del Instituto de Historia (Valparaíso, 1982), p. 20; también, profundizando en todo, sus estudios: La división politico-administrativa de Chile, 1541-1811 (Valparaíso, 1989), pp. 33 ss.; y Notas para el estudio de las Intendencias en el Chile Indiano, en Revista de Estudios Histórico-Jurídico, 11 (Valparaíso, 1986), pp. 109-141.

2 Véase la "Consulta de Amat a la Audiencia. Santiago, 27 de mayo de 1758", en Manuscritos Medina, 189, 4.338; y el "Informe de Juan Martínez de Rozas, asesor de la Intendencia de Concepción, sobre el estado político de la Provincia y los medios de extinguir la plaga de vagos, ladrones, etc., que la infestan, 1804", reproducido por CoBos, María Teresa, La institución del juez de campo en el Reino de Chile durante el siglo XVIII, en REHJ., 5 (Valparaíso, 1980), pp. 152 ss. Otros importantes testimonios aparecen desperdigadamente en el documentado artículo de Cовоs, María Teresa, precedentemente citado; consúltense también: Lorenzo, Santiago, Origen de las ciudades chilenas. Las fundaciones del siglo XVIII (Santiago, 1983), pp. 368 ss.; Cobos, María Teresa - Lorenzo, Santiago, Esquema de la administración de justicia en las áreas rurales chilenas, 1700-1786, en Revista de Derecho, 10 (Valparaíso, 1985), pp. 65-88. Entre los siglos XVII y XIX, el delito de abigeato también fue uno de los más difundidos allende los Andes; véase al respecto: LeVAGGI, A, El delito de abigeato en los siglos XVII, XVIII y XIX, en Revista del Instituto de Historia del Derecho "Ricardo Levene", 24 (Buenos Aires, 1978), p. 108. 
cuatrerismo; el cuatrerismo del vagabundo aparece como una nota concordante con rasgos generales de la sociedad rural chilena y de todo un medio histórico [...]”3. Los contemporáneos también lo entendieron así, y por los perniciosos ejemplos que ofrecía, no debe de extrañarnos que el legislador llegase a penar severamente la vagancia ${ }^{4}$. En verdad, vagabundaje y cuatrerismo aparecen en el dieciocho como una nota concordante con las condiciones existenciales de las comarcas, sociedad en que la falta de integración, la dispersión poblacional, la carencia de vías de comunicación, la marginalidad social que afectaba al mestizo, la disgregación familiar o el trabajo estacional complotaban contra todo intento por mantener la población en justicia y religión.

Más importante aún, y como consecuencia directa del alarmante grado que adquiere el hurto de ganado mayor y menor, es que en 1756 la autoridad política se aboca a la tarea de nombrar jueces de Comisión en los pagos cercanos a Serena, ello, con el fin de poner coto a "los continuos desórdenes que se hacen en el campo, robando ganados a los dueños de haciendas y cometiendo otros delitos [...]; [por ello es que] he tenido por conveniente dar Jurisdicción a esos [hacendados] para que puedan hacer sumarias, prender [a] los reos y remitirlos presos a las cárceles de las villas de su Jurisdicción" . Cinco años más tarde el arbitrio de tan previsora disposición era ampliado por el gobernador interino Félix de Berroeta al decretar "que en todos los Corregimientos del Reino se señalasen y deslindasen ciertos [y] proporcionados distritos, y en cada uno se nombráse persona de entera satisfacción y celo, para que con particular comisión de este Superior Gobierno e instrucción del Señor fiscal persiguiere con eficacia y [diligencia] a todo ladrón y vagabundo"'.

${ }^{3}$ Gongora, Mario, Vagabundaje y sociedad fronteriza. Siglos XVII a XIX (Santiago, 1966), p. 7. Sobre el vagabundaje en el Norte Chico, véase: Carmagnani, Marcello, El salariado minero en Chile colonial. Su desarrollo en una sociedad provincial: el Norte Chico 1690-1800 (Santiago, 1963), pp. 41 ss. La diferencia fundamental entre el vagabundaje del Norte Chico, respecto del de la zona central, la pre-frontera y la frontera fue la incorporación -mediante medidas semi compulsivas y compulsivas- de los marginados de la parte septentrional del Reino a las tareas mineras.

${ }^{4}$ Es por todos conocido que hoy en día la vagancia, estrictamente hablando, no constituye un delito en si mismo. Más otrora si lo fue, constituyéndose no sólo en una circunstancia agravante en el momento que los justicias punían la comisión de un delito, sino que fueron promulgadas sendas disposiciones legales ("bandos") cuyo objeto no fue otro que el de penalizar la acción de vaguear, ya que desde el mismo siglo XVI, la vagancia fue considerada como un género de vida próximo a la acción de delinquir. El artículo quinto de un "Bando de Buen Gobierno promulgado en 1788, que seguramente reeditaba disposiciones anteriores, ordenaba: "Que salgan inmediatamente de esta juridicción todos los vagabundos, ociosos y gente de mal vivir, pena de que, pasados tres dias, por el mismo hecho de hallarse sin oficio, empleo u ocupación servible y lícita, sean destinados a servir en obras públicas o reales, o en cuerpos de tropa de esta capital, o plazas de Valdivia, conforme a la naturaleza de los casos, por seis años, y que ninguna persona de cualquier estado o calidad los reciba, abrigue ni oculte en sus casas, pena de treinta pesos de multa o un mes de cárcel, según sus circunstancias" ("Bando de Buen Gobierno proveído por Ambrosio O'Higgins, 1788”, en "Fondo Capitanía General”, 811, pza. I.

5 "'Bando de Manuel de Amat y Junient. Santiago, 12 de mayo de 1756, en "Fondo Cabildo de Serena", 10, pza. 3.

6 "Bando de Félix de Berroeta. Santiago, 15 de diciembre de 1761", en "Fondo Cabildo de Serena", 18, pza. 1 . 


\section{LEGISLACIÓN APLICABLE A LA REPRESIÓN Y SANCIÓN Del delito de abigeato en el Reino de Chile}

1. Algunas disposiciones en el Derecho indiano chileno: bandos de gobernadores y corregidores y auto acordados de la Real Audiencia.

a) Bando de buen gobierno proveído por el gobernador José Antonio Manso de Velasco en 17397: "En vista del aumento de los hurtos de ganados mayores y menores se condena a la pena de muerte al que robare más de 5 cabezas de ganado mayor y 10 del menor, consultando a la Audiencia antes de su ejecución: los que delinquían en cantidades menores recibirian 100 azotes y destierro de 4 años en una fortaleza".

b) Bando de buen gobierno proveído por el gobernador interino Félix de Beroeta, en 1756: "Que por el primer hurto que cometiese cualquier reo siendo mestizo, mulato, negro o sambo si fuese de una cabeza de ganado mayor o de las de ganado menor se [le] diesen doscientos azotes, se le corte el pelo y se le rapen las cejas. Pues si fuese el hurto de dos cabezas de ganado mayor o cuatro de menor, [además] de los doscientos azotes, trazura de pelo y cejas fuese desterrado por un año a cualquiera de los presidios de Valdivia, Islas de Juan Fernández o [a] la Piedra que más proporcionáse la ocasión, creciendo según el aumento de los ganados mayores o menores, la pena de los años del destierro. Y siendo españoles los que cometiesen primero hurtos, se remitiesen con sus causas a la Real Audiencia para que determinase lo que fuese de Justicia. Que en caso de reincidencia, los mestizos, mulatos, negros o sambos aunque este segundo hurto fuese solo de una cabeza de ganado mayor o dos de [una] menor se les repitan los doscientos azotes, la trazura de pelo y cejas, sean desterrados a Chagre [¿Chagres?] por dos años aumentándose a proporción de las cabezas de ganado los años de destierro, reservando a la Real Audiencia la graduación de penas a los españoles que reincidieran y, finalmente que si creciese a tanto la insolencia del delincuente que castigado dos veces con temor de Dios y respeto a la Real Justicia [cometiese el] tercero hurto de una o más cabezas de ganado mayor, de dos o más del [ganado] menor se le aplique la pena ordinaria de muerte que prescriben nuestras leyes Reales".

c) Bando evacuado en Puchacay en 1764: "De acuerdo con el Bando Público de este Partido [Puchacay] se ordena aplicar la pena de azotes a los ladrones que incurran en hurtos menores y mayores"'.

d) Auto acordado de la Real Audiencia librado en 1796: "Siendo frecuente el robo de ganado, quedando en la impunidad frecuentemente los malhechores con detrimento de los dueños de las haciendas, deberán los jueces perseguirlos con la mayor actividad"10.

${ }^{7}$ Extracto reproducido por Gongora, M., cit. (n. 3), p. 10.

8 "Bando de Buen Gobierno proveído por el Gobernador Interino Félix de Berroeta, Santiago, 15 de diciembre de 1756", en "Fondo Cabildo de Serena”, volumen 18, pza. 1. Otras disposiciones, véanse en Cobos, M. T., cit. (n. 2), p. 123; Carmagnani, M., cit. (n. 3), pp. 46-47.

9 "Bando evacuado en Puchacay, 1764", en "Fondo Judicial de Puchacay”, vol. 114.

10 "Auto acordado de lo declarado por la Real Audiencia sobre la facultad de aplicar la justicia ordinaria la pena de azotes, Santiago, 6 de septiembre de 1796", en "Fondo Capitanía General", 811, pza. 62. 
e) Real providencia de la Real Audiencia emitida en 1796: "a los ladrones de ganado se les aplicará la pena de azotes y de vergüenza pública"11.

Respecto del Derecho indiano chileno y el delito que nos ocupa es importante verificar que el bien jurídico tutelado por las leyes no sólo se constituyó en uno de los más importantes instrumentos de que se valió el conquistador para impulsar y consumar la tarea colonizadora, sino que también, y desde un comienzo, la riqueza pecuaria se constituyó en una de las fuentes básicas de la frágil y estancada economía de Nueva Extremadura. Pensemos en el papel que jugó el caballo en el teatro de guerra de la frontera y el ultra Biobío; pensemos en la incidencia que ostentaron algunos subproductos ganaderos como las badanas, el sebo y los cordobanes en nuestra siempre deficitaria balanza comercial ${ }^{12}$; pensemos que la utilización del ganado caballar y mular hizo posible el transporte de productos hortícolas y frutícolas desde los centros periféricos de producción hacia los centros de consumo ubicados en el centro y, principalmente, hacia los puertos de exportación; pensemos que el empleo del caballo fue un importante elemento coadyuvante en la administración de justicia, especialmente en aquellos corregimientos excesivamente dilatados y de difícil topografía; pensemos que la carne se constituyó en el principal componente de la dieta alimenticia de los soldados acantonados en la "frontera de guerra", como también en la manutención de la guarnición y población carcelaria de la Plaza y Presidio de Valdivia ${ }^{13}$. Estas y otras consideraciones ayudan en no poca medida a explicar el interés de los justicias y de la autoridad política en lo que respecta a la mitigación del delito que nos ocupa. Empero, además de lo ya expresado, como también al hecho de que el abigeato ofrecía perniciosos ejemplos y perturbaba la tranquilidad pública, nos parece que el legislador mereció especial cuidado contrarrestar la acción de los cuatreros atendiendo a una consideración más de fondo y en la cual existía un estrecho nexo de unión entre el interés particular y el interés público. En efecto, si consideramos que por aquel entonces -siglo XVIII- el ganado mayor y menor que apacentaba en las fincas y predios rústicos carecía de custodia inmediata, vale decir, se encontraba alejado de la vigilancia de los que con buena fe y justa causa poseían, y si pensamos además que otrora las heredades estuvieron infradotadas de defensas pre constituidas -entiéndase linderos, términos o $\operatorname{cercos}^{14}$ - era na-

11 "Real providencia circular de la Real Audiencia”, Santiago, 6 de septiembre de 1796", artículos 2 y 4, en "Fondo Judicial de Talca", 1.227, pza. 2.

${ }^{12}$ Con respecto a la incidencia de la producción pecuaria en el comercio exterior de las regiones de Santiago, Serena y Concepción véase: el documentado estudio de CARMAGNANI, M., Les mecanismes de la vie economique dans une societé coloniale: Le Chili, 1680-1830 (Paris, 1973), pp. 33 ss.

${ }^{13}$ Sabemos que durante el siglo XVIII, Valdivia recibía anualmente 5.000 quintales de charqui, 400 de sebo y 800 botijas de gras; véase: GUARDA, Gabriel, La Economía de Chile austral antes de la colonización alemana. 1645-1850 (Valdivia, 1973), p. 33.

${ }^{14}$ Hecho que explicaría uno de los aspectos fundamentales de la institución de los préstamos de tierras que se verificó en las haciendas de la zona central durante el decurso del diecisiete: el precario tenedor debía "custodiar sus límites, y cuidar de que los ganados vacunos y caballares, que andaban grandes distancias sin pastor, no se extraviasen”; véase: GÓNGORA, M, Origen de los inquilinos de Chile central (Santiago, 1960), p. 41. 
tural que el legislador reforzara de alguna manera la tutela privada, que en este caso dependía de la fe pública y estaba por tanto permanentemente expuesta a ser vulnerada, y de paso cautelaba una de las riquezas básicas de la economía del Reino. En otras palabras, el legislador agravaba la sanción aplicable a esta clase de delito contra la propiedad -según cuales fueren las características locales y la frecuencia de su comisión-, al considerar por una parte, que la tutela privada se encontraba ciertamente disminuida, y por la otra, al sobrevalorar protegiendo -como corresponde hacerlo a todo pueblo que basa su economía en los productos primarios- la riqueza pecuaria.

Sin embargo, en cuanto a penología, rara vez se aplicó la pena de muerte a los cuatreros reincidentes. En verdad, los togados aplicaron fundamentalmente penas paralelas, vale decir, dos sanciones de distinta intensidad: azotes y pena de destierro en las obras del rey o en trabajos públicos verificados en las principales villas ${ }^{15}$. Con lo primero se satisfacía la vindicta pública, y con lo otro mediaba un evidente utilitarismo, considerando la infinidad de obras públicas en las que se necesitaba mano de obra "sedentaria".

\section{Derecho castellano supletorio ${ }^{16}$.}

Las fuentes castellanas, constitutivas del Derecho supletoria, estaban representadas por los siguientes cuerpos legales: i) Fuero Juzgo, lib. VII, tít. $3^{\circ}$, ley $23^{\mathrm{a}}$; ii) Fuero Viejo de Castilla, lib. II, tít. $3^{\circ}$, ley $4{ }^{\mathrm{a}}$; iii) Leyes de Estilo, ley 76a; iv) Fuero Real, lib. IV, tít. $13^{\circ}$, ley $3^{\mathrm{a}}$; y $v$ ) Partidas, VII, tít. $14^{\circ}$, ley $14^{\mathrm{a}}$.

Hemos omitido ordenar estas fuentes según el orden de prelación establecido

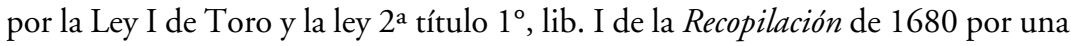
razón práctica: en lo que al abigeato respecta, la doctrina citada por defensores y acusadores aparece monopolizada por las Partidas. De lo anterior se infiere que el Derecho efectivamente vivido, en lo que respecta al supletorio aplicable al abigeato, fueron las normas sancionadas por Alfonso X el Sabio ${ }^{17}$. Nuestro aserto anterior explica lo inoficioso que hubiese sido consignar el tenor de los preceptos legales que aparecen en la Recopilación de las Leyes de los Reinos de las Indias, La "Nueva Recopilación" de Castilla y la Novisima Recopilación de Leyes de España. En todo caso, este último código llegó a aplicarse de facto en Chile recién a partir de $1816^{18}$.

\footnotetext{
${ }^{15}$ Véase: Pizarro, María, Jurisprudencia penal indiana. Delito de abigeato (Memoria de la Escuela de Derecho de la Universidad de Chile, Santiago, 1961), p. 24.

${ }^{16}$ Los textos completos en MARTínez, Marcelo, Códigos antiguos de España, desde el Fuero Juzgo hasta la Novísima Recopilación (Madrid, 1885).

${ }^{17}$ Eso se infiere del trabajo de Pizarro, M., cit. (n. 15), passim; allí se compulsan más de 300 casos por abigeato.

${ }^{18}$ Véase: Cousiño, Luis, Derecho penal chileno (Santiago, 1975), I, p. 74 n. 127.
} 


\section{DOS CAUSAS CRIMINALES POR ABIGEATO}

1. Causa criminal primera, caratulada: "Causa criminal contra Agustín Casanova por varios hurtos de caballos, 1792-1793"19.

a) La causa. En la villa de San Felipe el Real ${ }^{20}$, jurisdicción del partido de Aconcagua, Joseph Santos Mascayano, subdelegado de Intendencia y teniente a guerra del precitado partido ${ }^{21}$, dicta auto cabeza de proceso en contra de Agustín Casanova "por reincidencia en el abominable vicio de hurtos: se hallaba preso como lo habia sido en varias ocasiones ${ }^{22}$ por el expresado delito" 23 . De la lectura del auto cabeza de proceso fluye que el inculpado tenía por costumbre -ladrón consuetudinario- hurtar animales en el valle de Colina, y más grave aún, existía presunción que Casanova había perpetrado el homicidio de un pequeño, cuyo cuerpo habíase encontrado en uno de los ríos del valle de Putaendo.

La Audiencia envía requisitoria ${ }^{24}$ al juez diputado del valle de Colina, ordenándole iniciar las diligencias tendientes a esclarecer las circunstancias que rodeaban el hecho de sangre de que más arriba hicimos relación.

En la villa de San Felipe el Real, el subdelegado precitado conoce las declaraciones de cuatro testigos que culpan directamente a Casanova de la comisión de varios hurtos de animales. Joachen Cabrera, español, mayor de 50 años, manifiesta que conoce a "Agustín Casanova por público ladrón 25 y que a lo que se quiere acordar hacia cuatro o cinco años que habiendo hurtado en el valle de Santa Rosa de esta

${ }^{19}$ En "Fondo Real Audiencia”, 705, pza. 2, fs. 22.

${ }^{20}$ Villa cabezalera del partido de Aconcagua.

${ }^{21}$ Sobre el nombramiento, atribuciones y funciones de los subdelegados -justicias, que luego de entrar en vigor el fuero de intendentes en el Reino (1786), vinieron a suplir (aunque con atribuciones recortadas) en las esferas administrativas, legislativas, judiciales y militares a los fenecidos corregidores. Véase al respecto: Cobos, M. T., cit. (n. 3), pp. 95 ss.; Zorrilla, Enrique, Esquema de la justicia en Chile colonial (Santiago, 1942), pp. 45 ss.; CoBos, María Teresa, El régimen de intendencias en el Reino de Chile. Fase de implantación, en RChHD., 7 (Santiago, 1978), pp. 89 ss.

${ }^{22}$ La reincidencia fue sin lugar a dudas una de las más importante y recurrentes agravantes que esgrimieron los promotores fiscales y el fiscal de la Audiencia al momento de evacuar sus "proyectos de sentencia”; “...; La reincidencia en el mismo crimen [manifestaba un salvaguardador del ministerio público] de que ha sido castigado, lo constituye en ladrón famoso por tanto reo de muerte en acorde inteligente de las Leyes del Reino y Derecho común glosado de los mejores criminalistas...”. Extracto del dictamen, en "Fondo Capitanía General”, 292.

23 "Auto de cabeza de proceso contra Agustín Casanova, elaborado por el subdelegado de Aconcagua. San Felipe el Real, 1 agosto de 1792", "Real Audiencia”, 705, pza. 2, f. 1.

${ }^{24}$ Es decir, los despachos que generalmente remitían las justicias superiores a los jueces inferiores, con el objeto de que estos últimos ejecutaran una provisión o mandato.

${ }^{25}$ Es por todos ampliamente conocido que hoy en día una de las más importantes funciones de los jueces al momento de evacuar sentencia, consiste en sopesar de las declaraciones de los testigos -las que deben versar sobre las directas percepciones que el testigo ha tenido en relación a un hecho determinado- lo esencial de lo accidental. Mas del estudio de la documentación del dieciocho se infiere que el arbitrio judicial debió jugar un importante rol respecto de las declaraciones oídas y, en no pocas ocasiones en relación a la fama publica de los inculpados, las que si bien es cierto no constituían plena prueba, si desempeñaron un cometido nada despreciable en lo que respecta a la sustanciación de causas criminales. 
jurisdicción un caballo al testigo; otro a don Pedro Huerta y otro a Juan Severino, los que fue a vender a Petorca ${ }^{26}$, cerciorado el testigo de ello fue preso u puesto en esta Cárcel Pública de la cual fue remitido por uno de los señores Jueces de esta villa, que según le parece fue el Coronel Don Manuel de la Puente alcalde Ordinario, que era, a la ciudad de Santiago donde padeció cierta enfermedad por la que salió de aquella cárcel y antes de, reponerse de su salud, regreso a dicho valle, y ha continuado según voz común en el vicio de hurto, y por él, le han tenido preso los Jueces Diputados celadores de los Valles de Santa Rosa y Curimón y últimamente lo estuvo en esta Cárcel'27.

Por otra parte, Andrés Muñoz, español, 67 años, expresa "que en el mes de Mayo del presente año [Casanova] hizo uno que, habiéndole hurtado al testigo una yegua, casualmente una tarde de carrera[s] de caballos en la cañada de esta villa, encontré en ella, un hombre que no conocía" ${ }^{28}$. Aparte de sindicar a Casanova como ladrón de "voz pública", nuestro testigo manifiesta que por intermedio de Diego Muñoz, juez Diputado del valle de Curimón "sabe [que] le acumulan al dicho Casanova la muerte de un niño pequeño, por el interés de quitarle ocho o nueve reales que le mandaban llevar" 29.

Juan de Dios López, español, 26 años, en tanto, señala que por "ser voz publica, sabe que Agustín Casanova es ladrón de caballos y otros animales, y en particular sabe que, a Don Pedro Infante vecino del Valle de Santa Rosa le hurto un caballo ensillado, al testigo otro dicho que lo saco de un Potrero, a Santiago Olivos, otro caballo y a Agustín Celedon tres carneros" 30.

Finalmente, depone Antonio Navarro, español, de más de 30 años, quien manifiesta conocer al inculpado, asegurando asimismo que "por ser voz publica, sabe que el susodicho es ladrón de toda especie de animales y que a Pedro Infante, suegro del testigo, le robo un caballo ensillado"31.

El escribano de la villa de San Felipe el Real da fe de la actuación del ya mentado subdelegado en cuanto a las diligencias tendentes a recabar una eventual existencia de bienes pertenecientes al inculpado y, sobre las que pudiese recaer embargo, resultado "no habérsele conocido más, que el vestuario pobre que cargaba"32.

${ }^{26}$ Lo que descartaría una eventual remisión o atemperación de la pena invocando la eximente de hurto famélico, para la cual era indispensable la no concurrencia de fin de lucro en la comisión del delito.

27 "Fondo Real Audiencia”, 705, pza. 2, fs. 1 vta. a 3.

28 "Fondo Real Audiencia", 705, pza. 2, f. 3.

29 "Fondo Real Audiencia”, 705, pza. 2, f. 3.

30 "Fondo Real Audiencia", 705, pza. 2, f. 4.

31 "Fondo Real Audiencia”, 705, pza. 2, f. 4 vta.

32 "Fondo Real Audiencia”, 705, pza. 2, f. 6. Para la Monarquía española el hecho a la defensa fue una prerrogativa sagrada en la contienda judicial, incluso para los que por necesidad y estrechez no poseían los medios suficientes para procurarse adecuada defensa: nos referimos a los pobres de solemnidad o de notoriedad. Una de las más importantes diligencias de sustanciación de causa criminal consistía precisamente en recabar la eventual existencia de bienes en el inculpado; si los tenia se decretaba su embargo, en caso contrario, se dejaba constancia de ello en los autos y el procurador de pobres en lo criminal asumía de oficio su defensa. Sobre la declaratoria de pobreza, requisito indispensable para acceder a dicho beneficio, véase: la "Instrucción Circular, que con presencia de las anteriores firmadas, ordena el Señor Ambrosio Zerdan y Pontero, del Consejo de S.M. y su Fiscal del Crimen en esta Real 
Una vez concluidas las diligencias tendientes a completar la sumaria -vale decir, labrar auto cabeza de proceso, averiguación del delincuente a través de las deposiciones de testigos, prisión y embargo de bienes, declaración indagatoria y confesión del inculpado-, el subdelegado procede a remitir a Casanova a la Real Cárcel de Santiago, ingresando a esta en fecha 13 de octubre de 1792.

Diego Muñoz, juez diputado del valle de Curimón declara ante el alcalde de primer voto de cabildo de la villa de San Felipe el Real. Manifiesta "que conoce a Agustín Casanova, Natural del Valle de Santa Rosa, por publico ladrón de Caballos y Avios, por cuyos hechos le tuvo preso en dos ocasiones habiéndole en la primera hecho fuga $a^{33}$, y que en cuanto al homicidio que se dice haber ejecutado el Susodicho en un niño pequeño por Robarle ocho o Nueve reales, en la jurisdicción de esta villa

Audiencia para que les sirva de regla en la sustanciación de causas criminales... 22 de enero de 1778 [...]", en "Fondo Real Audiencia", 3.137, in folio. Véase también el "Auto de la Audiencia sobre la declaratoria de pobreza y el modo de acordarla, proveído en 1 de octubre de 1798", reproducido por Lira, José Bernardo, Legislación chilena no codificada (Santiago, 1881), I, p. 154-155. Sobre los deberes de los procuradores de pobres en lo criminales: CoRvalan, Jorge - Castillo, Vicente, Derecho procesal indiano, (Santiago, 1951), pp. 38-39.

${ }^{33} \mathrm{El}$ quebrantamiento de cárceles fue un problema permanente e insoluble durante el decurso del dieciocho. La causa de ello fue sin lugar a dudas la primitiva y precaria infraestructura carcelaria, incapaz de asegurar la permanencia de los reos, presentándose incluso algunas situaciones reñidas con las más elementales normas que exige la previsión: "[...] la noche de la fuga [reza en una sumaria levantada en 1779 , tras un quebrantamiento] de los presos de la Cárcel [de Santiago, los guardias] estaban sin cartuchos, ni Balas para las Armas, y solamente con los fusiles y Bayonetas, como lo estaban antes, y [lo] están también [en] el presente, por no darse los cartuchos, ni [las] Bala<s> [...]" ("Fondo Real Audiencia", 705, pza. 1). Ni siquiera las severas sanciones contempladas en el ordenamiento jurídico vigente lograban amilanar a los potenciales quebrantadores de cárceles. La Partida VII, titulo $29^{\circ}$ : De la guarda de los presos, ley 13a dice: "que pena deuen auer los presos que quebrantan la cárcel, o la prisión en que están señalaba: "Acordandose todo los presos que yoguiessen en vna carcel, o o en vna prision de quebrantar aquel lugar do los guardasen, e se fuesen todos, o la mayor parte dellos sin sabiduria de los guardadores, si despues desso fueren todos presos, o alguno dellos, también deuen los judgadores justiciar aquellos que despues desse prendieron, como si les fuesse prouado el yerro sobre que los tenian presos. Ca semeja que se dan por fechores de los yerros, de que eran acusados, porque ante que los judguen se acuerdan assi en vno en fuyr. Mas si por auentura non fuyessen, todos, mas algunos dellos, e después fueren presos otra vez, deuenles meter en mas fuertes prisiones, e aun de deuenles el judgador dar alguna pena por ende, según su aluedrio". Sobre las deficiencias del sistema carcelario y sus repercusiones en el Reino, véase: Coвоs, M. T., cit. (n. 3), pp. 144 ss. Para una visión de conjunto de las obligaciones del alcaide de la cárcel de Santiago, véase: "Instrucción que hace el fiscal de S. M. en lo criminal, para Gobierno del Alcayde de la Cárcel de esta Capital, en cumplimiento de lo mandado por los Señores Presidente, regentes y Oydores de esta Real Audiencia" (auto proveído en 16 marzo de 1887), en "Fondo Real Audiencia", 3.137, in folio. Los presidios existentes en los gobiernos político-militares tampoco escaparon a la situación de los quebrantamientos y fugas, difíciles de explicar si consideramos que tropas bisoñas -dado el carácter estratégico de los lugares- estaban encargadas de la custodia de los antisociales, y más todavía, si tomamos en cuenta el emplazamiento excéntrico de los presidios existentes en Valdivia y Juan Fernández. En lo que al presidio meridional respecta, al parecer la situación por momentos alcanzó grados alarmantes, ya que en 1779 el gobernador de la plaza y presidio elevaba una senda representación a la Audiencia en la que se refería la "[...] mucha deserción que se experimenta en esta [Plaza] [...]", proponiendo imponer la pena capital a los fugados, para así poner coto a la situación existente ("Fondo Real Audiencia", 2.839, pza. 4). 
solo sabe acumulársele este hecho por haberlo oído estando en la Puerta de la Cárcel publica de esta villa, y no tiene presente a quien ni que fue en ocasión que dicho Reo se hallaba preso en la referida Cárcel poco tiempo antes de ser remitido a la cárcel de la ciudad de Santiago" 34 .

En virtud de las declaraciones ya consignadas, y que en la práctica no arrojaban luz alguna en cuanto al esclarecimiento del hecho de sangre, el fiscal determina en otro auto "que [como] no hay otra constancia de este delito, bastamente atroz que aquel desnudo acerto ${ }^{35}$, puede V.A. siendo servido mandar se devuelva el proceso al subdelegado de Aconcagua [...]; adelantando las demás justificaciones que conduzcan al esclarecimiento del suceso [y] acompañe una copia de la partida de entierro del occiso, y remita las diligencias con la posible brevedad para que dicho corra la vista" 36 .

En 17 de noviembre de 1792 comparece ante el subdelegado de la villa de San Felipe el Real un nuevo deponente: Gregorio Vargas. Su testimonio aclara en no poca medida la situación de Casanova, por cuanto y a pesar de no conocer al inculpado "si tiene noticia de los Hechos que el Susodicho se le imputan, y que en cuanto a la muerte ejecutada en Alexandro [...]; sabe que Ignacio Basaez fue quien habiéndole quitado a dicho niño nueve reales que la referida su mujer le habia mandado llevar de lo de Eugenio Rodríguez como le siguiera [Basaez] instándole sin duda se lo devolviese encaminándole a la Vega que en la parte de el Poniente forman las orillas de este Rio, $y$ [en] un Estero le quito la vida" ${ }^{37}$.

En fecha 19 de enero de 1793, el fiscal de la Audiencia ordena tomar confesión al preso, la que se verifica dos días más tarde cuando ante el oidor decano y alcalde de Corte de la Audiencia el inculpado dice llamarse "Agustín Casanova, natural del Valle de Santa Rosa, Partido de Aconcagua, su estado soltero, su edad cerca de treinta años, su calidad español, su ejercicio Chacarero y que la causa de su prisión es porque habiendo estándole debiendo a Miguel Naveda cuatro pesos lo puso por ello el año pasado el jueza Diego Muñoz, quien pasados cuatro días lo puso en libertad para que limpiara trigo, y porque le pedia y demandaba Carcelaje se huyo, y por cuyo hecho se persuade lo volvió a hacer preso en la presente ocasión hasta [remitirlo] a esta Real Cárcel'38. Niega asimismo la veracidad de todos los cargos.

En la villa de San Felipe el Real, el 28 mayo de 1793, tienen lugar las ratificaciones de los testigos que anteriormente depusieron en la sumaria. Los testigos Antonio Navarro y Andrés Muñoz no concurren a dicho efecto, el primero por estar ausente de la jurisdicción, en tanto que el segundo había fallecido tiempo atrás.

El fiscal luego de examinar los autos originales en que aparecen consignadas las declaraciones de los testigos, evacua "proyecto de sentencia"; le parece que

34 "Fondo Real Audiencia", 705, pza. 2, f. 8 vta.

${ }^{35}$ Del parecer del fiscal, se infiere que el tenor de la deposición del testigo más arriba consignado no constituye plena prueba, toda vez que no existe otro deponente que se refiera directamente al hecho en cuestión.

36 "Reconocimiento de sumaria hecho por el Fiscal de la Audiencia. Santiago, 17 de octubre de 1792", "Fondo Real Audiencia", 705, pza. 2, f. 9 vta.

37 "Fondo Real Audiencia”, 705, pza. 2, fs. 9 y 9 vta.

38 "Fondo Real Audiencia", 705, pza. 2, fs. 12 y 12 vta. 
"el reo no ha tenido otro [delito] que el de robar caballos, y aunque en ha negado en su confesión, haber estado sirviendo en las obras Publicas en pena de sus delitos $y$ haberse encontrado en su poder el caballo de Don Pedro Infante [...]; [Por lo tanto, y considerando que Casanova es] un hombre Alagicioso, Ladrón, Vagamundo, y de tan perversa fama [...]; lo acusa en toda fuerza a la Pena de cien azotes y seis años de Destierro en uno de los Presidios del Reino o a la que fuere de Justicia" 39 .

El procurador de pobres en lo criminal asume la defensa del reo; manifiesta respecto de la pena solicitada por el fiscal que "por la calidad de las especies robadas como por no resultar estar ni aun simplemente justificadas del sumario, no solo no es digno a la prenotada pena, sino que estimando, con la prisión que ha sentido por superabundantemente con purgadas y al igual indicio resultado de culpabilidad contra el, se le ponga en plena libertad" 40 . Los fundamentos del procurador llegan más lejos aun, cuando expresa "que todos los testigos que le acusan, son todos infamantes y deponentes en propia causa, por cada uno de los cuatro, que costean el sumario [sic], lo primero que asientan en sus declaraciones es el robo ${ }^{41}$, que suponen haberlos hecho mi parte, refiriéndose del uno al otro para calificarle en esa fama publica de ladrón [...]; son ya [los hurtos] unos de un caballo, que tal vez no valdría el importe de dos reales, y ya otros de una yegua u otro ridículo animal' ${ }^{\prime 2}$.

El fiscal solicita el traslado de la publicación de probanzas ${ }^{43}$, a lo que accede el procurador de pobres en lo criminal. Posteriormente, seria este último quien procedería a idéntica acción.

En auto proveído por el regente se acuerda "cortar esta causa con el motivo de desahogar la Cárcel y lograr a la proposición que se presenta de remitir reos a Valdivia" 44 .

39 "Dictamen del Fiscal de la Audiencia. Santiago, 31 de enero de 1793", en "Fondo Real Audiencia", 705, pza. 2, fs. 13 y 13 vta.

40 "Fondo Real Audiencia", 705, pza. 2, fs. 13 y 13 vta. Altamente interesante resulta la exégesis al parágrafo anterior, si consideramos que el procurador solicita la remisión de una eventual condena invocando una atenuante muy socorrida en ese entonces: considerar la permanencia en prisión como pena cumplida.

${ }^{41}$ De las deposiciones de los testigos, fluye que la figura delictual es hurto y no robo. Al otro lado de los Andes también fue usual que se usase indistintamente las palabras hurto y robo. Véase: LeVAGGi, A., cit. (n. 3), p. 108.

42 "Fondo Real Audiencia", 705, pza. 2, f. 15 vta.

${ }^{43}$ La publicación de probanzas en el enjuiciamiento civil correspondía a "la unión y comunicación reciproca de las pruebas hechas en juicio por cada una de las partes, para alegar de bien probado en vistas de ellas, tachar a los testigos, o hacer lo que convenga a su defensa", Véase: Corvalan, J. - Castillo, V., cit. (n. 32), p. 148. En lo que respecta al enjuiciamiento criminal, la publicación de probanzas consistió en la oportunidad que se concedía a la defensa del reo para que alegase sobre hechos no considerados en primera instancia (entiéndase sumaria).

44 "Fondo Real Audiencia", 705, pza. 2, f. 18 vta. El tenor del auto en cuestión era sin lugar a dudas una flagrante transgresión a la Instrucción de regentes de 1776, si consideramos que el articulo XXIX de la misma ordenaba que: "Sera uno de los principales cuidados de los regentes, el informarse con frecuencia del estado que tienen los Pleitos en las Audiencias, para evitar que se impida su curso y determinación por medios ilegitimos, y dará las ordenes correspondientes a fin de que la Justicia tenga el debido y pronto servicio que le corresponde". Véase: Introducción de lo que deben observar los regentes de las reales audiencias de América: sus funciones, regalias, como se han de ver con los virreyes y presidentes y estos con aquellos (Madrid, 1776), reproducida por SALVAT, 
Los togados de la Audiencia acuerdan cortar la substanciación de la causa: "Vistos cortando esta causa en que se halla con el objeto de lograr la oportunidad que se presenta de remitir reos a Valdivia y el [de] desahogar la Cárce ${ }^{45}$ por el monto que de ella resulta [en la causa criminal] contra Agustin Casanova por ladrón de caballos se le condena en dos años de presidio y no lo quebrante y se le ejecute" ${ }^{46}$.

b) Comentario. Resulta en extremo difícil llegar a establecer la razón de fondo que mueve a los togados a cortar la sustanciación de la causa criminal que nos ocupa, si consideramos la existencia de la prohibición precitada. Podríamos especular bastante al respecto; empero y sin caer en inútiles devaneos, creemos que tan importante resolución se justificaría por: $i$ ) la oportunidad de desahogar la Real Cárcel de Santiago, que como todas las del período se encuentra "muy embarazada de reos" (razón práctica); ii) La inutilidad de proseguir el curso de la causa, pues la culpabilidad del reo es evidente (razón práctica); y iii) Poner fin a la excesiva preclusión que ha sufrido el reo, la que en el caso que nos ocupa es una atenuante acogida (razón humanitaria).

2. Causa criminal segunda, caratulada: "Criminal contra Domingo Abarca, $1794^{\prime 47}$.

a) La causa. En la Villa de San Fernando, subdelegación de Colchagua, Manuel Valenzuela, Guzmán, alcalde de primer voto de cabildo, dicta auto cabeza de proceso $^{48}$, ordenando se investiguen las actividades de Domingo Abarca, toda vez que "Juan Aguilera que hace de oficio de Mayordomo en la Estancia de Nicumlacta, [que] esta en las inmediaciones de esta Villa, [y] del dominio de Don Fernando de Quezada: le atraído a su presencia preso a un hombre que se asegura llamar Domingo Abarca, y que asimismo ha sido informado dicho alcalde de personas fidedignas, de distinción, y cristiano celo, que dicho Abarca ha echo varios robos de Caballos, Vacas y otras especies en estas inmediaciones; y para averiguar la Verdad Sobre estos hechos, y darle el Correspondiente Castigo: Debia demandar y mando formar este Auto que sirva de Cabeza de Proceso para que a su tenor, y por las Demás Circunstancias que resultaren, sean examinados los testigos que pudieren ser habidos, y que sean sabedores

Manuel, La Instrucción de regentes, en RChHD., 3 (Santiago, 1964), p. 63. Sobre el regente quien está encargado de velar por el buen funcionamiento administrativo económico de la Audiencia, véase: BrAVO, Bernardino, Judicatura e institucionalidad en Chile (1776-1886): del absolutismo ilustrado al liberalismo parlamentario, en REHJ., 1 (Valparaíso, 1976), pp. 72-73. Otros casos de condenas de reos a Valdivia, en "Fondo Real Audiencia", 1.335, pza. 2; 2.168, pza. 7; 2.477, pza. 8; 2.783, pza. 1; 2.786, pza. 6; 2.835, pza. 13.

${ }^{45}$ La documentación se prodiga en largueza respecto del exceso de población carcelaria en los recintos habilitados para mantener a buen recaudo a una florida gama de elementos antisociales. Este problema acapara -junto a la infradotación de grillos y el quebrantamiento de cárceles- la atención de los justicias en lo que se refiere a los problemas derivados de la precariedad de la infraestructura carcelaria.

46 "Fondo Real Audiencia", 705, pza. 2, f. 22.

${ }^{47}$ En "Fondo Real Audiencia", 2.348, pza. 9, 20 fs..

${ }^{48}$ En ausencia del subdelegado propietario a quien según el ordenamiento jurídico vigente correspondía conocer de las transgresiones que en materia criminal tenían lugar en la respectiva jurisdicción territorial a su cargo, según reza en el expediente que nos ocupa. 
de dichos robos, vida y costumbre del susodicho Domingo Abarca, concurriendo a todas las Demás Diligencias que se le ofrezcan del Real Servicio, y Causa Publica; $y$ asegúrese en la Cárcel, encargando su custodia al Teniente de Alguacil'49.

Ante el subdelegado de la Villa de San Fernando, Gregorio Dimas de Echaurren, deponen varios testigos: Juan Aguilera, español, señala "que con el motivo de estar a su cuidado la Hacienda de Don Fernando Quezada, y en ocasión de haber salido a dar vuelta a la Campaña (como tiene la obligación) [se] encontró con Domingo Abarca, Estanislado Camilo, y Lorenzo Romero quienes venían en tres caballos de Don Lucas Guzmán [...]; y haciéndoles cargo este declarante de aquellos Caballos ajenos, le respondieron, que venian del Cerro, y se les habian cansado sus Bestías, y [como] no tenemos como bajares, $y$ por este motivo los ensillaron, pero no Sabe este declarante Si las Largaron. Y teniendo sospecha este declarante, y Francisco Toledo, Vaguero de Don Luis Velasco de estos sujetos, trataron de a registrar un Bosque inmediato a las posesiones de estos en que tenían esta Sospecha: [y] encontraron [que] tenían una ternera muerta, oresrana, y asimismo Vestigios de que hubiesen muerto otras dos o tres Cabezas de Ganado Vacuno, por la inmundicia que en aquel paraje habian arrojado [...]; Mas dice este de un Decreto que le entrego Don Fernando Quezada su Patrón ${ }^{50}$, para que en consorcio del Cabo, Juan José Toledo prendieran a este dicho Domingo Abarca, lo aliaron en un Caballo robado a Don Antonio De la Torre, y también traía Carne de Vaca fresca debajo de los Pellones; lo prendieron, y condujeron a esta Cárcel [...]; También dice [el declarante] que el día siguiente le quito un caballo a Lorenzo Romero que acababa de esconder en el cerro, y que este dicho Romero era parcial en todo con Domingo Abarca [...]; Que también sabe que [a] Estanislado Camilo lo convido Domingo Abarca para robarle Ovejas a Don Fernando Quezada; lo que se le noticio por el mismo Estanislado delante del que declara: que sabe que al dia Siguiente llevaron [a] Domingo Abarca en compañia de Romero dos Cabezas de Ganado Ovejuno; como asimismo encontraron en la Manada una Bolsa Tabaquera, una Vaina ${ }^{51}$, y un señidor, cuyas prendas conoció Romero y dijo ser suyas, por donde

49 "Auto cabeza de proceso contra Domingo Abarca, labrado por el alcalde de primer voto de Cabildo, San Fernando, 30 de julio de 1794", en "Fondo Real Audiencia”, 2.348, pza. 9, fs. 1 y 1 vta. Es interesante constatar en este caso, que el auto cabeza de proceso aparece incoado - pocas veces sucedía así, al menos en materia criminal- por denuncia o delación de un tercero -en este caso, Juan Aguilera- y no de oficio como generalmente ocurría. De lo anterior se infiere que en algunas ocasiones, la participación de los habitantes de la campaña - como brazo auxiliar de la justicia. Era importante y operaba cuando superaban esa no pequeña cuota de reverente temor a la venganza. Sobre ese último acápite véase: CoBos, M. T., cit. (n. 3), pp. 138-139.

${ }^{50}$ La expresa mención al decreto en cuestión, estaría indicando-creemos-, que Aguilera procedía, cuando puso en manos de la justicia al mentado Abarca, investido de jurisdicción delegada por su patrón, quien debió de haber sido juez de comisión. Si bien es cierto que a los que impetraban justicia delegadamente -como los jueces de comisión- les estaba expresamente vedado delegar la propia, fue usual que lo hicieran, hecho que se habría impuesto por la necesidad y la costumbre. Este aserto constituye, una interpretación del autor que debe tomarse con beneficio de inventario pues debe probarse documentalmente.

${ }^{51}$ En la documentación a que hemos tenido acceso, no hemos topado con disposición alguna que taxativamente hubiese penalizado la tenencia de armas en despoblado. En lo que a las villas respecta, si sabemos que fueron promulgadas sendas disposiciones legales que 
se vino en conocimiento que era este cómplice en el robo de Ganados ${ }^{52}$. Que también sabe que Domingo Abarca hizo fuga estando preso por la Iglesia en esta cárcel. Que también sabe por habérselo dicho Estanislado Camilo que Domingo Abarca con Romero le mataron a Don Lucas Guzmán una Vaca, en la Olla""33.

Por su parte, el segundo testigo, Estanislao Camilo, manifiesta al subdelegado "que con el motivo de haber ido en dos ocasiones en días festivos a casa de Domingo Abarca, vio que tenían en el fuego asando Carne de Vaca fresca; y la ultima ocasión que fue reparo que le pregunto Lorenzo Romero a dicho Abarca, que si quedaba carne $y$ le respondió Abarca que sí, que todavía estaba escondida en el Monte la que quedaba: que entonces se le descubrieron a este declarante, y lo convidará para que les ayudase acarrear que fue la Cabeza, y el cuero y aunque le dijo Abarca a este declarante, que aquella Vaca que habian muerto era de la madre de Abarca, que la habian escondido por que no se enojase: y dice este declarante, que como le cupiese de suerte haber llevado

castigaban severamente la tenencia de armas. Un "Bando de buen gobierno promulgado por Ambrosio O'Higgins en 1778", dice en su cuarto artículo: "que nadie cargue armas cortas de fuego, ni de acero, como pistoletes, puñales, dagas, estoques, espadas de más de marca, o cuchillos de punta, ni otro instrumento agudo punzante para herir. Ningún mercader las venda, ni ningún maestro armero las haga ni componga. Usándose solo de las permitidas para los sujetos privilegiados, ministros de justicia, y de resguardos de rentas reales que tengan licencia o título por escrito de este supremo gobierno. Pero a cualquier individuo que se hallare con armas ofensivas sin estas circunstancias, [condénesele] de cuatro meses de prisión siendo noble, y de servicio en el presidio los mismos [meses] al que no lo fuere [como vemos, la calidad de los individuos incide en la configuración de una escala penal para un mismo delito, ya que, entre cumplir una pena en prisión o en presidio existía una notable diferencia], por la primera vez; un año, por la segunda; $i$ destierro por dos años [entiéndase presidio, sea en el presidio de Juan Fernández o en la Plaza y presidio de Valdivia] al que reincidiera por tercera, con gravamen de doscientos azotes por las calles o al pie de la horca, teniendo colgado al cuello el instrumento de su delito, a los plebeyos [ahora vemos que la calidad de los individuos influye en la forma de ejecutar la pena]; entiéndase lo propio con los que cargaren macanas, laques, piedras sueltas [es interesante observar que el legislador en este caso no solo considera como un arma solo a aquellos instrumentos que específicamente fueron creados para herir o dañar a las personas, sino que también a un importante número de instrumentos que, pueden ser transformados en arma, en cuanto tanto sean utilizados como instrumento contundente], $y$ los individuos de castas y campestres que usaren ojal, y botón o hebilla en las acciones de los estribos con lados en sus avios de montar a caballo, de los que se suelen valer para reñir", en "Fondo Capitanía General", 811, pza. 1. Otro "Bando de buen gobierno datado en 10 de febrero de 1788 y proveído por Ambrosio de Benavides" dice lo que sigue: "Ninguna persona que baja esfera, traiga consigo Armas largas, o cortas, como Espada, Daga, Puñal, Cuchillo, Palo o Piedras, pena de cincuenta azotes, que luego incontinente, se ejecutara en el mismo Sitio donde fuere hallado el transgresor [...]; y asimismo la de dos meses de Destino a la Cadena y a trabajar a las obras publicas de esta ciudad [...]", en "Fondo Real Audiencia", 3.137, in folio.

${ }^{52}$ De la deposición de Aguilera, pareciera inferirse que el ya mentado Abarca formaba parte de una banda (entendemos como banda, a aquella asociación ilícita permanente, que tiene por finalidad la comisión de una pluralidad de delitos continuados; en este caso homogéneos: abigeato), junto a Romero y un tercero que ya aparecerá en los autos. Si bien es cierto que hoy en día la participación en una banda amada aparece más bien como una agravante calificada del robo, en el dieciocho la fue también respecto del hurto y estuvo especialmente vinculada al delito de abigeato.

53 "Fondo Real Audiencia", 2.348, pza. 9, fs. 2 a 3 vta. 
la Cabeza a Casa de Abarca reparo que no era la señal con que señala la madre de Abarca si no otra distinta, como ser, una oveja pilora, y la otra rajada, con un ramal colgando. También dice que habiendo ido otro día de fiesta a Casa de Abarca vio que le pidió a su madre una cabeza de Ganado, y se la negó, y que [de camino] fue en compañia de Romero a pie con un lacito en la mano, y llegaron a la ocasión con dos cabezas de Ganado muertas y que no sabe de quién serian. También dice este declarante que habiendo [asistido] otro día de fiesta a casa de Abarca, lo convido para que fueran a robarle una oveja a Don Fernando Quezada, y le respondió que para que era esa maldad, y se vino para la Villa [...]" ${ }^{54}$.

Francisco Toledo en tanto, manifiesta que junto a cuatro o cinco jinetes "hallaron una ternera de año orejana, (y no supiera de quien era) a distancia de tres cuadras de la casa de Domingo Abarca, y que asi este declarante, y Juan Aguilera, recogieron la carne, como ser [también] una Espaldilla, el espinazo, y el cuero. Que también sabe que cuando prendieron a dicho Abarca andaba en un caballo de Pedro Amiano, que [es] del Potrerio de Don Antonio de la Torre, se lo habia robado con otro caballo de José Espinoza el dicho Abarca [...]; que también explorando este declarante con los compañeros que lleva dicho, encontraron en la misma quebrada donde hallaron la ternera muerta, encontraron vestigios de que se hubieran muerto y beneficiado otros dos cabezas de ganado Vacuno" 55 .

Otro testigo, José Poblete, declara "que conoce a Domingo Abarca, y sabe que a Don Antonio de la Torre le robo dos caballos los cuales se encontraron en poder de dicho Abarca. Y que a los vaqueros Ilamados Juan Aguilera y Francisco Toledo: el primero del servicio de Don Fernando Quezada, y el segundo de Don Luis Velasco, les oyó decir que a Don Lucas Guzmán le robo dicho Abarca una vaca, y tres caballos y que dichos robos los hiso en compañia de Estanislado Camilo y Lorenzo Romero, y que los caballos que lleva expresados fueron ensillados para coger la vaca [...]; que sabe que [a] Florián San Martin le robo dicho Abarca, otro caballo [...]" 56.

Finalmente, comparece José Espinoza, manifestando "que sabe que Domingo Abarca rompió el candado y goznes de la Puerta del Potrero de Don Antonio de la Torre y que habiendo faltado [luego] dos caballos de dicho Potrero, que el uno de estos dichos caballos, andaba dicho Abarca cuando lo prendieron, y el otro confeso el mismo estaba guardada en el Cerro por él, en el cerro en una Olla, y con efecto se hallo dicho caballo..." 57 .

Finalizados las deposiciones de los testigos, el subdelegado de la Villa de San Fernando ordena -en día 2 septiembre de 1794- tomar confesión al reo: "dice llamarse Domingo Abarca que es natural de esta villa, que es de edad de veinte y cinco años, que es mestizo, que es soltero, que su oficio es [el de] labrador, y que sabe la causa de su prisión, que es por una Vaca, y un Buey que le achacan. [Después] fue le preguntado a quien robo dicha Vaca y Buey en donde y cuando. Responde que el no a robado dichos animales [...]; Fuele hecho cargo de tres caballos y que robo junto con Estanislado Camilo y Lorenzo Romero perteneciente a Don Lucas Guzmán;

\footnotetext{
54 "Fondo Real Audiencia", 2.348, pza. 9, fs. 4 y 4 vta.

55 "Fondo Real Audiencia", 2.348, pza. 9, fs. 5 vta. y 6.

56 "Fondo Real Audiencia", 2.348, pza. 9, fs. 6 vta. y 7.

57 “Fondo Real Audiencia”, 2.348, pza. 9, f. 7 vta.
} 
Respondió que es cierto que Francisco Toledo y Juan Aguilera lo encontrara en dichos caballos de Don Lucas Guzmán, [nosotros] los ensillaron en el cerro por habérsele cansado sus Bestias con ánimo de saltarlas, las que al día siguiente soltó este confesante en el cerro. Fue echo el cargo de una ternera orejona muerta que Juan Aguilera y Francisco Toledo encontraron muerto en el Bosque en las inmediaciones de la casa de este confesante, y asimismo de los vestigios que encontrara de haber muerto otras dos cabezas de Ganado Vacuno. Responde que no sabe de los vestigios, y que solo la ternera es cierto por que era de su madre [...]; Fuele echo cargo de dos caballos que robo del Potrero de Don Antonio de la Torre uno perteneciente al dicho, y otro de José Espinoza, y de la carne fresca que traía de bajo de los pellones cuando lo prendieron y trajeron a esta dicha cárcel, y se le apercibe diga la verdad ${ }^{58}$. Responde que es cierto que en responder tenía el caballo de Don Antonio de la Torre, pero que lo bubo de un mozo (cuyo nombre so sabe) y la Carne era de la ternera que encontraron en el bosque [...]; Fuele preguntado de un caballo que al día siguiente le quitaron a Lorenzo Romero que acababa de esconder en el cerro compañero dicho Romero de este confesante...; Responde que el dicho Romero solía llegar a su casa por ser compañero y amigo, y que a oído decir que el caballo que encontraron escondido seria de Don Antonio de la Torre, y que a su juicio seria robado junto con el otro [...]; Fuele hecho cargo de haber convidado a Estanislado Camilo para robarle ovejas a Don Fernando Quesada...; Responde que él no a convidado [a] dicho Estanislado Camilo por robar dichas ovejas. Fuele reanquido [sic] como dice que no le convidado [a] dicho robo cuando de la sumaria consta haberle convidado, adonde se conoce que en todo está faltando a la verdad y asi que responda el hecho de ellos [...]; Responde que el no a echo convite [...]; Fuele hecho cargo de dos cabezas de ganado ovejuno que este confesante llevo a su casa el día siguiente. Y que en la majada donde estaba dicho ganado se encontró una bolsa tabaquera, una vaina y un ceñidor, cuyas prendas, [re] conoció Romero y dijo ser suyas. Responde que él ni Romero [han] llevado tales cabezas de ganado, ni sabe nada acerca de las prendas...; Fuele hecho cargo de una Vaca que la mato junto con Romero a don Lucas Guzmán en la Olla [...]; Responde que en nada se halla Culpable. Fuele hecho cargo de un caballo que robo a Pedro Amaro del Potrero de Don Antonio de la Torre. Responde que ya tiene dicho [que esa] res que fue

\footnotetext{
${ }^{58}$ Durante la segunda mitad del siglo XVIII, dos instrucciones referidas a un conjunto de reglas para la substanciación de causas criminales se ocuparon de los requerimientos, advertencias y amonestaciones de los jueces, en lo que a la confesión judicial respecta. La primera data del 25 de agosto de 1757 y fue concebida por José Perfecto Salas; la segunda fue aprobada por la Audiencia en Auto Acordado de 16 de marzo de 1778 y su autor fue Ambrosio Zerdan de Landa Simón Pontero. El tenor de esta última en lo que a la confesión se refiere, señalaba: "[...] se le tome su confesión, haciéndole cargo de los hechos que resultan probados, ni menos empeñarse ofreciendo libertad a los reos negativos, porque confiesen, ni tampoco atemorizándole con azotes, destierro y otro castigo". Véase: "Instrucción circular, que con presencia de las anteriores formadas, ordena el Señor Don Ambrosio Zerdan y Pontero, del Consejo de S.M. y su Fiscal del Crimen en esta Real Audiencia para que sirva de regla en la substanciación de causas criminales", en "Fondo Real Audiencia", 3.137, in folio. La promulgación de estas dos "Instrucciones" para la materia que nos ocupa era capital, pues derogaba de hecho la aplicación del título $30^{\circ}$ (De los tormentos), leyes $1^{\text {a a }} 9^{\text {a }}$ de las Partidas en Chile. Se tendrá presente que los códigos más antiguos de España no mencionan el tormento.
} 
comprada [...]. Fuele hecho cargo de haber convidado a Estanislado Camilo la carne que junto con Lorenzo Romero tiene escondida en el Monte y que habiendo ido dicho Estanislado ha ayudarle ha acarrear [la], la cupo delante traer la cabeza, y vio que la una oreja tenia pilona, y otra vergada con un ramal colgando. Responde que una vez que haya avido [¿oído?] quien lo haga declarado, será robada [...]; Fuerenle echas otras varias preguntas y repreguntas, y échasela cargo como con poco temor de Dios, y respeto a la Justicia está faltando a la Religión del juramento pues niega enteramente todos los delitos de que es acusado. Responde que no a faltado en nada al juramento sino que a dicho en todo la verdad, ni acometido en la vida ningún delito, so cargo del juramento dicho en que se afirmo" 59 .

En fecha 9 septiembre de 1794, Mateo de Argomedo es nombrado Promotor fiscal ${ }^{60}$ en la causa criminal que nos ocupa. Tres días después, evacuaba su dictamen, el que no dejaba de ser interesante, si consideramos la inclusión de preceptos que indudablemente fundamentaban el tenor de la sanción que sigue: "desde la recepción de él a este Partido [el Promotor fiscal ] se he empeñado su atención en la corrección de delitos por cuyo medio, se habia tranquilizado [el Distrito], pero hoy que parece principiar a la Reincidencia de tan detestables inclinaciones, como el expresado reo, para moderarle su carrera: le parece al Promotor se le aplique al destino de cinco años a uno de los presidios en Santiago a ración y sin sueldo y Perpetuo extrañamiento de este Partido" 61.

En fecha 19 septiembre de 1794, Fermín Guerrero, es nombrado de oficio defensor del preso $^{62}$. El defensor inicia el alegato correspondiente, manifestando

59 "Fondo Real Audiencia", 2.348, pza. 9, fs. 9 a 11 vta.

60 "Los promotores fiscales, acusadores o agentes fiscales como también se los llamó, eran funcionarios que ejercían su oficio junto a los tribunales inferiores”. Véase: MADRID, Elena, El ministerio público en el Derecho indiano, en MLVI (Santiago, 1950), p. 31, passim. Al parecer la labor de los promotores fiscales -quienes, junto al fiscal del Consejo de Indias y a los fiscales de las audiencias ultramarinas representaban en grado eminente la persona del soberano y salvaguardaban el interés general de la corona- no fue relevante, y se circunscribió solo a la tarea de informar con respecto a la pena que debía de aplicarse en las causas criminales. Si comparásemos las atribuciones y responsabilidades del fiscal de la Audiencia, con las de los promotores fiscales, es evidente que las de estos últimos estaban bastante menguadas en relación al primero. Los fiscales debían tener, como expresamente señalaba Felipe III: "gran Cuydado dela defenza y conservación demi Juridiccion. Patronazgo y Hacienda Real y danme quenta, con particular relación de todo lo que en esso hubieran y de quanto convenga ami Real Servicio". Véase: "Ordenanzas de la Real Audiencia de Chile otorgadas por Felipe III en 17 febrero de 1609", en "Fondo Real Audiencia", 3.137, in folio.

61 "Dictamen del promotor fiscal. San Fernando, 12 septiembre de 1794", "Fondo Real Audiencia”, 2.348, pza. 9, f. 12 vta.

${ }^{62}$ Así como la rapidez y gratuidad en la administración de justicia, fueron sin duda alguna uno de los caros ideales de la monarquía española, el Derecho a la defensa fue algo sagrado en la contienda judicial. Así también lo entendieron los togados de nuestra Audiencia: "suelen en campaña donde no hay abogado ni procurador de pobres, y en que los reos comúnmente son rústicos, y gente inculta nombrarles defensor, y es buena práctica para que los procesos no se substancien sin alguna defensa. Y este da un escrito satisfaciendo a los cargos, y cuida de presentar los testigos que ofrecen el reo para que se examinen": "Instrucción para la substanciación de causas criminales, concebida por José Perfecto Salas, 25 agosto de 1757", en "Fondo Real Audiencia”, 3.137 in folio. 
"que [de] la sumaria no le resulta al reo en que se le condene al Promotor por fundarse solo esta [acusación] en mera presunción de los testigos que la componen, y en consecuencia, que por ello no debe el Reo ser preso y haber sufrido la dura prisión de cuatro meses" ${ }^{63}$. En cuanto al testimonio de Juan Aguilera, el defensor manifiesta que "todo lo otro [declarado por Aguilera] no le justifica que Abarca sea el ladrón por que en una confesión aparece el descargo que la ternera era de su madre, y siendo que ella tiene varios de estos animales no deja de sorprender solo el que sea u otro el caballo no pudo haberlo ensillado y haberlo hallado ensillado por haberlo hallado aparecido y para que conociere dueño montarlo que es común estilo las prendas resultan ser de Romero como lo declaro Aguilera, por consiguiente seria Romero y no Abarca el ladrón de las ovejas. Los caballos de Don Lucas resultan de los testigos, que los soltaron, y no siendo cosa nueva que en necesidad de hallarse a pie que tome lo ajeno siendo como lo hizo haberlo soltado para agravio le resulto al dueño [...]; La Vaca muerta en la olla que Estanislado Camilo le acusa no era de ningún crédito este trabajo cuando resulto compliese en el mismo hecho que Abarca y si aquel es preso por ello por que no está siendo digno de notar que aun asi aparece, castigado en la sumaria ${ }^{64}$. Y en estos casos de flagrancia, por esto no es mucho que se cargue a Abarca [...]; que las provisiones para condenar al Reo deben ser más claras que la hora meridiana parece que se halla en la prisión absoluta y reprender a los que han sido causa de su prisión a fin de que

63 “Fondo Real Audiencia”, 2.348, pza. 9, f. 14. La prisión prolongada otrora se constituyó en una de las atenuantes más socorridas por los procuradores en lo criminal, lo que es explicable si consideramos que en muchas ocasiones sucedía "que los reos permanecían en prisión preventiva por tiempo indefinido y se ofrecian situaciones en que el número de reclusos a la espera de juicio atestaba las cárceles ordinarias, porque la falta de tiempo o el olvido hacían que se pasase por alto la obligación de ventilar el proceso en los términos previstos", CoBos, M. T., cit. (n. 3), p. 149. Un Auto acordado de 1757 señalaba al respecto: "[...] que todos los corregidores y demás Jueces ordinarios de las Villas y Partidos de este Reino, procedan en las Causas Criminales, o bien sean de oficio, o bien a pedimento de partes arregladas a Derecho substanciándolas por breves, y sumarios términos con audiencia de los mismos reos, recibiéndolos a prueba y ratificando los testigos de las sumarias dentro de este termino de ella, de manera que en treinta dias contados del de la Prisión queden concluidas para sentencia, y en estado de ella los remitan a esta Real Audiencia y los reos a la Cárcel, para que se pronuncie la Sentencia correspondiente a los méritos del Proceso" ("Auto acordado del 3 agosto de 1757: para que los Corregidores concluyan las causas criminales", en "Fondo Real Audiencia", 3.137, in folio. También topamos con un bando proveído por la Audiencia en 1796, el que en su art. 6 señala: "Para establecer un método para abreviar la conclusión de los procesos criminales, se ordena que en las causas criminales de oficio y aun en las promovidas entre partes, siendo los delitos ligeros, o puesta la acusación por el Ministerio Fiscal, se de traslado al reo y se reciba la causa a prueba reservándose el Tribunal en caso de que las pruebas llegaren a desvanecerse o se debiliten los delitos, comunicar nuevo traslado al Ministerio Fiscal para que pida la absolución del reo o menor pena" ("Bando de lo declarado por la Real Audiencia sobre la facultad de aplicar la justicia ordinaria la pena de azotes, 29 agosto de 1796”, en "Fondo Capitanía General”, 811, pza. 62. Sobre otros autos de la Audiencia relacionados con esta materia, véase: Cовоs, M. T., cit. (n. 3), p. 149, nota 143.

${ }^{64}$ Según parece, el defensor olvidaba que "la sentencia dada contra el autor de un delito, no aprovechaba ni dañaba al cómplice de él, aunque juntamente en una acusación o libelo fueran acusados y contra ellos juntos se siguiera la causa. Así se podía ejecutar la sentencia contra uno de ellos estando en estado, aunque no lo estuviere contra el otro". Vid. CORVALÁn, J. - Castillo, V., cit. (n .32), p. 228. 
en lo sucesivo no sean causa de los procedimientos de los miserables, por tanto pido y suplico se tenga asi probarlo que es justicia" ${ }^{65}$.

En fecha 7 septiembre de 1794, el subdelegado recibe la "causa a prueba con termino de nueve días con todos [los] cargos de publicar para oír sentencia y entre de dicho termino se ratifiquen los testigos que han declarado en esta sumaria" ${ }^{66}$; hecho que solo se verifica entre los días 2 y 10 de noviembre del mismo año.

Toda vez concluida la sumaria y ratificados el tenor de los respectivos deposiciones, el subdelegado de San Fernando, con fecha 11 de noviembre, remite al reo y los autos originales de la causa criminal que nos ocupa a la Audiencia. En fecha 14, el fiscal recibe la causa.

El dictamen del fiscal de la Audiencia rezó así: "Vistos por lo que del proceso resulta contra el reo Domingo Abarca se le Condene en veinte y cinco azotes en el Rollo ${ }^{67}$ y cuatro meses de servicios en el Presidio de Tajamares apercevido no lo quebrante por lo que la sufrirá doblado y se le impondrán las más graves penas que corresponden y que en lo sucesivo arregle sus operaciones por de lo contrario será castigado con todo el rigor de los justicias" 68.

En noviembre de 1794, Juan José de la Torre, procurador de pobres en lo criminal, asume la defensa del preso. En su primera actuación manifiesta a la Audiencia, respecto a la causa del promotor fiscal de San Fernando [...]; que aquellos Providencias son "agravantes a mi parte (hablando con la veneración debida). Suplico de ella, y para poder lo hacer instruir se hace servir su Superior Justicia mandar se me entreguen los autos para el termino de la ley en La Forma Ordinaria"69.

Luego de examinar los autos originales de la causa, el procurador fundamenta su alegato, señalando "que como se conocerá del proceso si la cosa se hubiese de juzgar según los estrictas formalidades de las leyes este hombre, no puede ser convencido de ningún delito. No hay un testigo [-agrega-] que conteste con otro ni tampoco el que no elquia deposición se infiera un robo cierto lo que únicamente consta es que tomo un caballo pero también que lo soltó in mediatamente y dejo en la misma hacienda sobre todo ya y según esta bien informado el procurador han aparecido los animales vacunos que se le imputaban como se podia justificar en caso necesario no fuesen más penosas las dilaciones en una materia tan corta"70. La última parte de los considerandos del procurador-que más adelante veremos-son aun más interesantes y los que, creemos, al fin de cuentas habrían gravitado sobremanera al momento en que los togados de la Audiencia evacuaran sentencia definitiva. El procurador señalaba que el reo tenía "una miserable madre que ha venido de San Fernando y des pues de haber vendido cuanto tiene se halla cuasi de mendiga y a cuya vista se le traerá aponer en el Rollo. Tiene hermanos decentemente casadas cuyos maridos necesariamente las han de aborrecer y abandonar con deshonor de este desdichado, y todo se origina de unas especies

\footnotetext{
${ }^{65}$ "Fondo Real Audiencia”, 2.348, pza. 9, fs. 14 y 14 vta.

66 "Fondo Real Audiencia”, 2.348, pza. 9, f. 15.

${ }^{67}$ Picota hecha de piedra, alternativamente en forma redonda o de columna.

68 "Dictamen del Fiscal de la Audiencia. Santiago, 25 noviembre de 1794", en "Fondo Real Audiencia”, 2.348, fs. 15 vta. y 16.

69 "Fondo Real Audiencia”, 2.348, pza. 9, f. 17.

70 "Fondo Real Audiencia", 2.348, pza. 9, f. 18.
} 
tan misérrimas que aun que las hubiese tomado para sostener la vida cuasi seriamos culpables por ser tan urgente esta necesidad y la naturaleza ${ }^{71}$, este mucha esto que acibadadamente (sic) no tiene veinte y un año, jamás a hecho daño a persona alguna ni se ha visto preso una vez que tomo fide de su madre y [...]; Teniendo presente la verdad de [señalar] en no haber concurrido a la Sublevación de la Cárcel de San Fernando sin embargo de hallarse alli preso como lo expone el Señor fiscal ${ }^{72}$ todo que suplico a V.I.A. causa también que le sirvan dispensar los dichos tramites por la falta de tiempo con la inmediación de la Santa Pascua por lo que formo el recurso que mejor convenga a la justicia"73.

Vistos los autos, y los escritos presentados por el procurador de Pobres, el fiscal evacúa su dictamen en la causa criminal que nos ocupa "[...] que en honor y reverencia de la Próxima Pascua de Natividad, podre V. A. siendo servido, y por un efecto de Equidad suspendido la pena de los veinte y cinco azotes, que debía sufrir en el rollo, según la Providencia referida o resolver lo que fuere de Justicia"74.

Sentencia de la Audiencia: "teniendo consideración a la larga prisión que ha sufrido Domingo Abarca ya que en el Proceso no se halla bastante comprobado el delito que se le imputa ${ }^{75}$ : y según lo que nuevamente se alega por el procurador de Pobres aun han [a]parecido las Vacas que se le atribuian robada de Cosentinente del Señor fiscal de S.M. y en honor y Reverencia la próxima Pascua de Natividad se le suspende la pena de los veinte y cinco azotes que habia de sufrir en el Rollo, y también la prisión que está sufriendo, apercibido severamente que en lo sucesivo arregle y modere sus operaciones no juntándose con personas sospechosas, y dedicándose al trabajo para poder ganar su Vida, pues de lo contrario a la menor queja será castigado con todo el rigor de las leyes y se hará mérito a la presente Causa"76.

b) Comentario. Si bien es cierto que la remisión de la pena a un reo era prerrogativa privativa del monarca, las audiencias estaban facultadas - por delegación de la potestad real: ¿derogación de la ley?- “para [...] visitar: [generalmente en la víspera de las Pascuas de Natividad, Domingo de Ramos y Pentecostés] a todos los presos por la real jurisdicción ordinaria que se hallen en las cárceles [...]; y ponerlos en libertad o ampliarles la carcelaria, salvo los casos que se suelen excepcionar en las

\footnotetext{
${ }^{71}$ Aquí el procurador de pobres está invocando como atenuante el hurto famélico o estado de necesidad, excepción, otrora bastante socorrida por los procuradores. El estado de necesidad como causa genérica de justificación de una acción delictual no deja de ser figura interesante: atempera la sanción, no obstante el bien jurídico sacrificado es a su vez un bien protegido por el ordenamiento jurídico vigente. En causa criminal que nos ocupa, en consonancia con los testimonios, resulta indudable que esta atenuante no procede.

${ }^{72}$ Bastante extraño pues ello no aparece consignado en los autos. En todo caso, es una atenuante importante.

73 "Fondo Real Audiencia", 2.348, pza. 9, fs. 19 y 19 vta.

74 "Dictamen del Fiscal de la Audiencia. Santiago, 23 diciembre de 1794", en "Fondo Real Audiencia", 2.348, pza. 9, f. 19 vta.

${ }^{75}$ Peculiar que los togados de la Audiencia se expresen así, pues nos parece que de las deposiciones de los testigos se infiere la culpabilidad del reo.

76 "Auto de sentencia de la Audiencia. Santiago, 24 diciembre de 1794", en "Fondo Real Audiencia", 2.348, pza. 9, f. 20.
} 
cédulas de indultos generales[...]"77. Las excepciones estaban constituidas especialmente por los crímenes de lesa majestad ${ }^{78}$.

\section{BiBLIOGRAFÍA}

Ávila, Alamiro de, Esquema del Derecho penal indiano (Santiago, 1941).

BRAVO, Bernardino, Judicatura e institucionalidad en Chile (1776-1886): del absolutismo ilustrado al liberalismo parlamentario, en REHJ., 1 (Valparaíso, 1976).

Carmagnani, Marcello, Les mecanismes de la vie economique dans une societé coloniale: Le Chili, 1680-1830 (Paris, 1973).

Carmagnani, Marcello, El salariado minero en Chile colonial. Su desarrollo en una sociedad provincial: el Norte Chico 1690-1800 (Santiago, 1963).

Coвos, María Teresa, La división territorial de Chile y sus modificaciones", (17001818) en Coloquios de los Profesores del Instituto de Historia (Valparaíso, 1982).

Cовоs, María Teresa, La división político-administrativa de Chile, 1540-1810 (Valparaíso, 1989).

Совоs, María Teresa, Notas para el estudio de las intendencias en Chile Indiano, en REHJ., 15 (Valparaíso, 1986).

Cobos, María Teresa, La institución del juez de campo en el Reino de Chile durante el siglo XVIII, en REHJ., 5 (Valparaíso, 1980).

Coвos, María Teresa, El régimen de intendencias en el Reino de Chile. Fase de implantación, en RCHHD., 7 (Santiago, 1978).

Совоs, María Teresa - LoREnzo, Santiago, Esquema de la administración de justicia en las áreas rurales chilenas, 1700-1786, en RDX (Valparaíso, 1986).

Corbalán, Jorge - Castillo, Vicente, Derecho procesal indiano, en ML XX (Santiago, 1951).

Cousiño, Luis, Derecho penal chileno (Santiago, 1975).

Gongora, Mario, Vagabundaje y sociedad fronteriza. Siglos XVII a XIX (Santiago, 1966).

GÓNGORA, Mario, Origen de los inquilinos de Chile central (Santiago, 1960).

GUARDA, Gabriel, La Economía de Chile austral antes de la colonización alemana. 16451850 (Valdivia, 1973).

LeVAgGi, Abelardo, El delito de abigeato en los siglos XVII, XVIII y XIX, en Revista del Instituto de Historia del Derecho Ricardo Levene, 24 (Buenos Aires, 1978).

LiRA, José Bernardo, Legislación chilena no codificada (Santiago, 1881).

LorEnzo, Santiago, Origen de las ciudades chilenas. Las fundaciones del siglo XVIII (Santiago, 1983).

Madrid, Elena, El Ministerio Público en el Derecho indiano, en MLVI (Santiago, 1950).

Martínez, Marcelo, Códigos antiguos de España, desde el Fuero Juzgo hasta la Novísima Recopilación (Madrid, 1885).

${ }^{77}$ Avila, Alamiro de, Esquema del Derecho penal indiano (Santiago, 1941), p. 51.

${ }^{78} \mathrm{En}$ el curso de nuestra investigación topamos casualmente con dos células reales que conceden indulto general: la primera data del 8 de junio de 1780 y la segunda del 16 de enero de 1784. Ambas en "Fondo Real Audiencia", 2.839, pza. 13 y 15 respectivamente. 
Pizarro, María, Jurisprudencia penal indiana. Delito de abigeato ( Memoria de la Escuela de Derecho de la Universidad de Chile, Santiago, 1961).

Salvat, Manuel, La Instrucción de regentes, en RChHD., 3 (Santiago, 1964).

Zorrilla, Enrique, Esquema de la justicia en Chile colonial (Santiago, 1942). 